\title{
Improving Organizational Citizenship Behavior Through Development of Transformational Leadership and Work Satisfaction
}

\author{
Hari Muharam*, Widodo Sunaryo, Arwan Gunawan \\ Prodi Administrai Pendidikan \\ Universitas Pakuan \\ Bogor, Indonesia \\ *hari.muharam@unpak.ac.id
}

\begin{abstract}
This study aims to find an effort to improve Organizational Citizenship Behavior (OCB) through research on the relationship between transformational leadership and job satisfaction with OCB. The method used in this study is a descriptive correlational method using a quantitative approach. The population in this study is the Permanent Teacher Foundation in 9 Private Vocational Schools in Cibungbulang District, Bogor Regency with a total of 117 teachers. The sampling technique uses proportional random sampling with the Slovin formula with a 5\% margin error with a total sample of 91 teachers. This study concludes that there is a positive relationship between Transformational Leadership and Organizational Citizenship Behavior. The strength of the relationship between Transformational Leadership (X1) and Organizational Citizenship Behavior (Y), 2) There is a positive relationship between Job Satisfaction and Organizational Citizenship Behavior. The strength of the relationship between Job Satisfaction (X2) and Organizational Citizenship Behavior (Y), 3) There is a positive relationship between Transformational Leadership (X1) and Job Satisfaction (X2) together with Organizational Citizenship Behavior (Y) which is indicated by the ry12 correlation coefficient $=\mathbf{0 . 6 8 5}$ and Transformational Leadership and Job Satisfaction together have a contribution of 46,9\% of Organizational Citizenship Behavior.
\end{abstract}

Keywords: citizenship behavior, transformational leadership, work satisfaction

\section{INTRODUCTION}

Education, in general, has the meaning of a life process in developing each individual to be able to live and carry on life. With sufficient education, insight, extensive knowledge will be able to prepare superior young people who can build this nation and country better. Education has the task of preparing quality human resources so that when a nation needs for a development to be more advanced then educated people will be needed. Basically, education provides knowledge of how to behave, speak words and learn developments that can ultimately be used for a large audience. But what is happening now is education becoming a place to make a living and can be said to do business. Various ways people do to get a bachelor label to be accepted at an agency and not a few who take the wrong path to get a high salary then moral education should also be applied.

In each study of educational science, issues relating to teachers and teacher positions are always mentioned, even becoming one of the subjects that have its place amid education science that is so broad and complex. Nowadays the attention is getting bigger in connection with the progress of education and the increasing needs of teachers, both in quality and in number. One of the factors causing the low quality of education in Indonesia is the teacher, often heard news about the behavior of one teacher who cannot be used as an example by students so that the behavior of students also follows the mistakes made by these teachers in this case a teacher is less able to understand personality competencies which should be owned by a person who is predicated as a teacher. Other problems teachers also often force the will without ever paying attention to the needs, interests, and talents of their students. They have never explored the problems and potential of students; education should pay attention to the needs of children instead of imposing something that makes children less comfortable in studying. A good educational process is to provide opportunities for children to be creative.

Professional teachers start from competent teachers, the relationship between teachers and students is never spared from teaching and learning activities, the teaching and learning process is the core of the formal education process with the teacher as the main role holder. In the teaching and learning process, some learning outcomes are determined by the teacher's role. Competent teachers will be better able to create an effective learning environment and be able to manage the teaching and learning process.

The reality that occurs in educational organizations (schools), teachers still tend to carry out tasks based on standard workloads and tend not to contribute more to school progress. This contribution was later known as Organizational Citizenship Behavior (OCB). According to Jahangir et al. OCB referred to as a series of behaviors in the workplace that exceeds a person's basic needs [1]. This is often described as 
the behavior that goes beyond the call of duty. The indicators that show OCB include: a) Altruism, namely Behavior Helping new colleagues and freely giving time to others, usually directed to other individuals but contributing to group efficiency by increasing individual performance, b) Conscientiousness, namely Behavior Use of time efficiently and beyond the minimum expectations that can improve the efficiency of both individuals and groups, c) Sportsmanship namely Behavior to avoid complaining and whining, thereby increasing the amount of time spent on constructive efforts in the organization, d) Courtesy for example Behavior helps prevent problems and facilitates constructive use of time, e ) Civic Virtue, which is the Behavior of Serving and attending events voluntarily and in terms of promoting organizational interests.

Kinicki and Williams suggested that OCB is the behavior of employees who indirectly do work beyond what is required by the organization [2]. The characteristics of OCB's behavior according to their opinion include: a) Constructive and caring behavior towards the organization; b) Behavior likes to help others; c) Behavior provides suggestions for organizational progress; d) Behavior willing to survive in an unpleasant situation without complaining; e) Attendance behavior exceeds standards.

OCB is a citizenship behavior that benefits the organization and exceeds formal obligations. It was also stated that OCB not only includes positive behavior, but also the quality of patience and willingness to bear the occasional costs. The indicators that reflect OCB are as follows: a) Helping other employees without coercion / voluntary; b) Tolerance for the inconvenience that arises; c) Participate actively in organizational activities; d) Defend the organization from external threats and roles that exceed the minimum standards.

Based on the above theory, it can be concluded that OCB is employee behavior that is voluntary to work beyond its formal work obligations without expecting any compensation from the organization, with the following indicators: a) Altruism: Refers to the behavior of wanting to help coworkers who experience difficulties in the organization, $b$ ) Conscientiousness: behavior that exceeds the minimum role requirements expected by the organization, c) Sportsmanship: Behavior Tolerating Conditions under ideal conditions, without excessive complaints, d) Courtesy: Behavior prevents various problems related to work, e) Civic virtue: Behavior that shows constructive individual involvement in organizational processes that exceed the minimum demands of his work.

According to Colquitt et al., transformational leadership is a leadership that involves inspiring all members to commit to a common vision that gives meaning to the development of their potential and some problems from a new perspective [3]. The indicators of transformational leadership are as follows: a) Idealized influence / charisma, leaders have a clear and purposeful vision (sense of purpose), then transformational leaders are able to win the trust and respect of their followers, b) Intellectual stimulation / intellectual stimulation, active leaders looking for new ideas and new ways of doing things, c) Individualized consideration / individualized attention, leaders pay attention to the needs and personal development potential of each of their followers, d) Inspirational motivation / inspirational motivation, leaders motivate people who are led, arouse enthusiasm, set an example, seen as taking part in bearing the burden.

Leslie and Lioyd suggest that transformational leadership is a leadership style that can create conditions of mutual motivation between leaders and followers, so leaders can change followers for the better and create a sense of trust from followers to leaders [4]. The indicators are a) Employee relations with managers which is one of the joint stimulations and is characterized by the charisma of the leadership; b) Inspiration by the leader; c) Considerations by leaders on individual needs; d) Intellectual stimulation between leaders and employees.

Ivancevich et al., suggested that transformational leadership is the leadership that can expand and increases the interest of followers to be able to do something beyond their interests for the benefit and good of others [5]. The indicators are a) Charismatic (Charisma); b) Inspiration; c) Intellectual Stimulation; d) Individualized Consideration (individualized considerations).

Lee also argues that transformational leadership is the leadership that can motivate followers to do more than they should [6]. Transformational leaders set goals for their followers to pursue but transformational leadership takes it a step further because followers are encouraged to go beyond their self-interests to achieve common goals while also developing their skills to achieve targets beyond those shared goals. With indicators: a) Charisma is a personal power or personal attraction that leads to acceptance and liking by followers. b) Intellectual stimulation is the ability to increase followers' awareness of problems and their capacity to suggest possible solutions to overcome them. c) Individual consideration is the ability to evaluate individual potential and help people to realize their promises.

Erkutlu also argues that transformational leadership refers to leaders who move followers beyond direct self-interest through idealized influence (charisma), inspiration, intellectual stimulation, or individual consideration [7]. With indicators: a) The ideal influence and inspirational leadership are displayed when leaders imagine the desired future, articulate how it can be achieved, set examples to be followed, set high-performance standards, and show determination and confidence. Followers want to identify with leadership like that. b) Intellectual stimulation is displayed when leaders help followers become more innovative and creative. c) Individual consideration is displayed when leaders pay attention to the development needs of followers and support and practice the development of their followers.

Based on some of the above theories, it can be concluded that transformational leadership is the behavior or actions of leaders who inspire and motivate their followers to work better to achieve results that are by shared goals. The indicators are a) Charisma. Leaders Have a Clear Vision and involve the role of members/followers to carry out their duties properly. b) 
job. The influencing factors are: a) salary, b) benefits, c) promotion opportunities, d) supervision, e) coworkers, f) working conditions, g) the nature of the work itself, h) communication and i) security. Rini also explained that job satisfaction is the feeling of workers towards their work based on an assessment of aspects in their work [13]. The indicators are: a) Satisfaction with salary (wages), b) Satisfaction with promotion, c) Satisfaction with colleagues (d), d) Satisfaction with superiors (supervisor), e) Satisfaction with work. Shane and Glinow also suggest that job satisfaction is one's evaluation of work and himself in the context of his work [14]. The indicators that influence it are a) Characteristics of perceived work, b) Work environment, c) Emotional experience at work.

Based on some of the above theories it can be concluded that job satisfaction is the attitude and feeling of workers towards their work that shows the extent to which individuals feel positive or negative about their work. The indicators are a) Salary / Wages (Pay), Is a factor of fulfilling the needs of life of employees who are considered appropriate or not. b) Promotion (promotion), is a factor related to the presence or absence of opportunities to gain career advancement during work. c) Workers (Workers), Is a factor related to the relationship between employees with their superiors and with other employees, both the same or different types of work. d) Superiors (Supervision), a good superior means willing to appreciate the work of his subordinates. For subordinates, the boss can be considered a father/mother/ friend figure and at the same time his boss. e) Work itself (Work Itself), Every job requires a certain skill by their respective fields. Difficult whether or not a job and someone's feeling that their expertise is needed in doing the job, will increase or reduce job satisfaction.

\section{METHODS}

The method used in this research is a descriptive correlational method using a quantitative approach, which describes the relationship between transformational leadership (transformational leadership) and job satisfaction with organizational citizenship behavior. The population in this study was the Permanent Teachers Foundation (GTY) in 9 Private Vocational Schools in the District of Cibungbulang, Bogor Regency with a total of 117 teachers. The sampling technique uses proportional random sampling with the Slovin formula with an error margin of $5 \%$. The number of samples used in the study was 91 teachers. The research data that has been collected will be analyzed by descriptive statistics and inferential statistics.

\section{RESULTS AND DISCUSSION}

The first hypothesis testing concluded that there was a very significant positive relationship between Transformational Leadership and Organization Citizenship Behavior as indicated by the count of 13,195 , greater than the value of the table at the 0.05 alpha significance level, namely 1,980 or $13,195>1,980$. The relationship pattern between these two variables is expressed by the regression equation $=\mathrm{a}+\mathrm{bX} 1$ or $=98,063+$

$0,324 X 1$. This equation provides information that every change
Spector suggests that job satisfaction is an attitude that reflects how a person feels about his work as a whole and various aspects of the job [12]. In simple terms, job satisfaction is the extent to which someone likes his job and job dissatisfaction is the extent to which someone does not like his 
relationship pattern as shown by the regression equation mentioned above. This means that if all Permanent Teachers of Private Vocational Foundations in Cibungbulang Sub district, Bogor Regency are measured about Job Satisfaction, the variation of the score pairs of the two variables will be distributed and follow the pattern of Relationship between Job Satisfaction and Organizational Behavior Organization through the equation of the regression line $=\mathrm{a}+\mathrm{bX} 2$ or $=88,337+$ $0.388 \times 2$.

Hypothesis testing concluded that there was a very significant positive relationship between Transformational Leadership and Job Satisfaction together with the Organization Citizenship Behavior as indicated by the Fcount value of 12.370

The relationship pattern of the three variables expressed by the multiple regression equation $=65.769+0.262 \mathrm{X} 1+$ $0.263 \times 2$. This equation provides information that each change of one-unit score of Transformational Leadership and Job Satisfaction of one unit will result in changes in Organization Citizenship Behavior of 0.262 and 0.263 at a constant of 65.769 .

The results of the multiple correlation analysis between Transformational Leadership and Job Satisfaction obtained a double correlation coefficient value of ry.12 of 0.685 . This value shows that the relationship between Transformational Leadership and Job Satisfaction together with the Organization Citizenship Behavior is positive. The amount of contribution or contribution of Transformational Leadership and Job Satisfaction variables together can be known through the coefficient of determination of 0.685 . The results of the analysis show that approximately $48.9 \%$ of variations in changes in the Organization Citizenship Behavior are determined/explained by Transformational Leadership and Job Satisfaction together with their functional relationship patterns as shown by the regression equation mentioned above. This means that if all teachers are examined Transformational Leadership and Job Satisfaction together by looking at the Organization Citizenship Behavior, then variations in the score pair of the three variables will follow the pattern of regression equation $=65.769+0.262 \mathrm{X} 1+0.263 \mathrm{X} 2$.

\section{CONCLUSION}

There is a positive relationship between Transformational Leadership and Organizational Citizenship Behavior. The strength of the relationship between Transformational Leadership (X1) and Organizational Citizenship Behavior (Y) is indicated by the correlation coefficient ry1 $=0.603$ and Transformational Leadership contributes $36.4 \%$ to Organizational Citizenship Behavior. To improve Organizational Citizenship Behavior, it is necessary to pay attention to improve the teacher's civic virtue behavior, appreciation is one of the most important factors to be considered and improved, this can be done by giving awards both verbally and non-verbally to teachers who have the ability, creation, and achievement in working. understanding that approximately $25.9 \%$ of the variance in changes in the Organization Citizenship Behavior is determined/explained by its Job Satisfaction with its functional 


\section{ACKNOWLEDGMENT}

There is a positive relationship between Job Satisfaction with Organizational Citizenship Behavior. The strength of the relationship between Job Satisfaction (X2) and Organizational Citizenship Behavior ( $\mathrm{Y}$ ) is shown by the correlation coefficient ry $2=0.509$ and Job Satisfaction contributes $25.9 \%$ to Organizational Citizenship Behavior. Things that need to be considered in improving the leadership of school principals is to increase Individualized consideration by listening attentively and giving special attention, support, enthusiasm, and effort to the needs of teacher achievement and growth. Have special attention to the needs of teachers in achieving and the growth that teachers expect by behaving as a leader. Teachers are developed successfully in increasing their potential. This consideration greatly influences teacher satisfaction with the principal's leadership and can increase teacher productivity. Considerations arise among others in the form of treating teachers individually and expressing appreciation for each good teacher's work.

There is a positive relationship between Transformational Leadership (X1) and Job Satisfaction (X2) together with Organizational Citizenship Behavior (Y) as indicated by the correlation coefficient ry12 $=0.685$ and Transformational Leadership and Job Satisfaction together have a contribution of 46, 9\% of Organizational Citizenship Behavior. To increase teacher job satisfaction, schools need to consider the conditions of teacher welfare related to the salary/wages received by the teacher. This is evident from the teacher's attitude towards his work, a positive attitude if satisfied or a negative attitude if not satisfied. Teacher dissatisfaction regarding salaries received can be expressed in various ways. For example, teachers complain, disobey, or avoid part of their work responsibilities. While job satisfaction is one of the goals to be achieved by every teacher in his workplace. The existence of a satisfied teacher makes work morale, dedication, love, and teacher discipline increase. For this reason, it is imperative for school principals to pay attention to the welfare of their teachers, emphasize teachers to be clever in managing the income they receive, and a school principal must be able to actively motivate teachers and must be able to influence the level of teacher job satisfaction, if job satisfaction needs to be improved, the principal must intervene and help create an atmosphere that encourages, supports, and maintains improvement.
This research was supported by Universitas Pakuan Foundation. We thank to Prof. Dr Bibin Rubini, M. Pd who provided insight and expertise that greatly assisted the research, although he may not agree with all of the interpretations of this paper.

\section{REFERENCES}

[1] J. Nadim, M.A. Mohammad and H. Mahmudul, "Organizational Citizenship Behavior: Its Nature and Antecendents". BRAC University Journal, Vol. 1, No. 2, pp. 75-85, 2004.

[2] A. Kinicki dan B.K. Williams, Management A Practical Introduction. New York: McGraw-Hill, 2008.

[3] J.A. Colquitt, J.A. Lepine, and M.J. Wesson, Organizational Behavior. New York: McGraw-Hill, 2011

[4] W. Rue, Leslie dan L. Byar L. Supervision : Key Link to Productivity, Ninth Edition. New York : Mc Graw-Hill, 2007.

[5] J.L. Gibson, John M. Ivancevich, James H. Donelly.Jr., dan Robert Konopaske, Organization Behavior, Structure Processes.New York : Mc Graw Hill Companies Inc, 2008

[6] L. Mei "Transformational Leadership: Is It Time For A Recall?," International Journal of Management and Applied Research, Vol. 1, No 1. pp.18, 2004.

[7] H. Erkutlu, "The impact of transformational leadership on organizational and leadership effectiveness The Turkish case," Journal of Management Development Vol. 27 No. 7 pp. 708-726, 2008

[8] J.L. Gibson, J.M. Ivancevich, J.H. Donnelly, Jr., and R. Konopaske, Organization: Behavior, Structure and Processes. New York: McGrawHill, 2006.

[9] P. Stephen, Robbins and A. Timothy, Organizations Behavior, 15th edition.New York : Pearson Education, Inc, 2010.

[10] J. Wood, J. Wallace and R.M. Zeffane, Organizational Behavior : A Global Perspective, 2nd edition.Milton Qld : John Willey and Sons Australia, Ltd, 2001.

[11] S, Niroshaan and G.F. Cynthia, "Emotional intelligence, moral reasoning and transformational leadership," Leadership \& Organization Development Journal 23/4 pp.198-204, 2002.

[12] E.S. Paul, Industrial and Organizational Psychology : Research and Practice, fifth edition. New Jersey : John Wiley \& Sons, 2008.

[13] D.P. Rini, "Pengaruh Komitmen Organisasi, Kepuasan Kerja Dan Budaya Organisasi Terhadap Organizational Citizenship Behavior (OCB) (Studi Pada PT. Plasa Simpanglima Semarang)," Jurnal Ilmiah Dinamika Ekonomi Dan Bisnis Vol. 1 No. 1. Hal. 78, 2013.

[14] F. Luthans, Organizational Behavior: An EvidenceBased Approach. New York: McGraw-Hill. Mc Shane and Von Glinow.(2010) Organizational Behavior Emerging Knowledge an Practice for the real World. New York McGraw-Hill Companies, Inc, 2011. 